Laporan Penelitian

\title{
Hubungan merokok dengan gangguan pendengaran akibat bising pada pekerja pabrik kelapa sawit $\mathbf{X}$
}

\author{
Maesyara Adinda Sari*, Adlin Adnan*, Delfitri Munir*, \\ Putri Chairani Eyanoer** \\ *Departemen Telinga Hidung Tenggorok - Bedah Kepala Leher, **Epi-Treat Unit \\ Fakultas Kedokteran Universitas Sumatera Utara/Rumah Sakit Haji Adam Malik \\ Medan
}

\begin{abstract}
ABSTRAK
Latar belakang: Paparan bising dapat mengakibatkan kerusakan pada organ korti, dan menurunkan aliran darah koklea yang mengakibatkan hipoksia koklea. Merokok diketahui sebagai ototoksik langsung dan pemicu iskemia koklea. Kebiasaan merokok dan paparan bising secara sendiri ataupun secara bersama-sama dapat menyebabkan gangguan pendengaran. Tujuan: Mengetahui hubungan merokok terhadap kejadian gangguan pendengaran akibat bising (GPAB). Metode: Penelitian analitik dengan pendekatan potong lintang. Hasil: Dari 122 pekerja, didapati sebanyak 89,3\% pekerja mengalami GPAB. Tuli ringan paling banyak ditemukan $(68,8 \%)$. Didapatkan adanya hubungan yang signifikan antara tipe perokok dengan derajat beratnya $\operatorname{GPAB}(\mathrm{p}=0,000)$. Kemungkinan pekerja yg merokok untuk mengalami GPAB 1,224 kali lebih besar dibandingkan dengan pekerja yang tidak merokok $(\mathrm{PR}=1,224, \mathrm{p}=0,002, \mathrm{CI}$ $95 \%=1,077-1,392)$. Kesimpulan: Terdapat hubungan yang signifikan antara kebiasaan merokok dengan kejadian GPAB.
\end{abstract}

Kata kunci: Merokok, gangguan pendengaran, gangguan pendengaran akibat bising, bising lingkungan kerja

\section{ABSTRACT}

Introduction: Noise exposure can lead to the organ of corti damage, and decrease the blood flow to the cochlea resulting in cochlear hypoxia. Cigarette smoking could be ototoxic to cochlea, and could evoke cochlear ischemia. Cigarette smoking habit and noise exposure, each or together can cause hearing loss. Objective: To identify the correlation between cigarette smoking and noise induced hearing loss (NIHL). Method: Analytic with a cross-sectional study. Results: From the 122 workers, we found that the proportion of NIHL was $89.3 \%$. Mild deafness was most common (68.8\%). We found that there was a significant correlation between type of smokers and grade of hearing loss $(p=0.000)$. Workers who smoked likely to undergo NIHL 1.224 times greater than nonsmokers ( $P R=1.224, p=0.002, C I$ 95\%=1.077-1.392). Conclusion: There was a significant correlation between cigarette smoking habit and noise induced hearing loss.

Keywords : Cigarette smoking, hearing loss, noise induced hearing loss, occupational noise exposure

Alamat korespondensi: Dr. Maesyara Adinda Sari. Departemen Telinga Hidung Tenggorok - Bedah Kepala Leher, Fakultas Kedokteran Universitas Sumatera Utara/Rumah Sakit Haji Adam Malik, Medan. Email: dr.dindasari@yahoo.com. 


\section{PENDAHULUAN}

Gangguan pendengaran akibat bising (GPAB) sering dijumpai pada pekerja industri di negara maju maupun negara berkembang, terutama negara industri yang belum menerapkan sistem perlindungan pendengaran dengan baik. Indonesia sebagai negara yang sedang berkembang dalam upaya meningkatkan pembangunan, banyak menggunakan peralatan industri yang dapat membantu dan mempermudah pekerjaan. Sebagai akibatnya, timbul bising lingkungan kerja yang dapat berdampak buruk terhadap para pekerja. ${ }^{1}$

Bising di lingkungan kerja merupakan masalah utama kesehatan kerja di berbagai negara. Berdasarkan data dari World Health Organization (WHO), sekitar 16\% dari seluruh populasi dunia menderita tuli akibat bising yang disebabkan oleh paparan bising di lingkungan kerja.,3

Kebiasaan merokok merupakan masalah penting dewasa ini. Rokok oleh sebagian orang sudah menjadi kebutuhan hidup yang tidak bisa ditinggalkan dalam kehidupan sehari-hari. Berdasarkan Riset Kesehatan Dasar (Riskesdas) 2013 didapatkan bahwa rerata proporsi perokok di Indonesia adalah 29,3\%. Berdasarkan jenis pekerjaan, diketahui bahwa petani/nelayan/buruh (pekerja pabrik) menempati proporsi perokok aktif setiap hari yang terbesar, yaitu $44,5 \%{ }^{4}$

Pada tahun 2005 dilakukan studi terhadap tikus putih yang diberi paparan asap rokok dan didapati bahwa asap rokok berpengaruh pada kerusakan integritas histologis koklea. Kerusakan koklea pada kelompok pajanan asap rokok lebih besar dibandingkan kelompok kontrol dengan relative risk (RR) sebesar $3,5 .^{5}$

Efek kombinasi dari kebiasaan merokok dan paparan bising merupakan efek adiksi. Paparan bising selain mengakibatkan kerusakan pada reseptor pendengaran organ korti di telinga dalam juga mengakibatkan menurunnya aliran darah koklea yang mengakibatkan keadaan hipoksia koklea. Merokok dilaporkan dapat berperan sebagai ototoksik langsung (efek nikotin) dan sebagai pemicu terjadinya iskemia koklea melalui mekanisme produksi karboksihemoglobin, vasospasme, meningkatkan viskositas darah dan kerjanya yang berhubungan dengan arteriosklerosis pembuluh darah serta menyebabkan disfungsi endotelial. Sehingga berdasarkan teori diatas kebiasaan merokok dan paparan bising dapat mengganggu koklea untuk menjalankan fungsinya. ${ }^{6-8}$

Pada tahun 2003 dilakukan penelitian terhadap 4.624 pekerja pabrik baja di Jepang yang menyatakan bahwa efek kombinasi dari merokok dan terpapar bising di lingkungan kerja kemungkinan bersifat adiktif terhadap GPAB. ${ }^{9}$ Penelitian serupa dilakukan pada tahun 2010 terhadap tenaga kerja perusahaan produksi gerbong kereta api di Iran, didapatkan kejadian GPAB sebanyak $26,9 \%$ pada kelompok perokok dan 6,2\% pada kelompok bukan perokok. Hal ini berarti kemungkinan terjadi GPAB pada kelompok perokok yang terpapar bising adalah 5,6 kali lebih besar dibandingkan kelompok yang tidak merokok. ${ }^{10}$

Penelitian ini bertujuan untuk mengidentifikasi hubungan kebiasaan merokok terhadap kejadian gangguan pendengaran akibat bising (GPAB) di sebuah pabrik kelapa sawit.

\section{METODE}

Penelitian ini merupakan penelitian analitik dengan studi cross sectional. Pengambilan data dilakukan di Pabrik Kelapa Sawit (PKS) X mulai Juni 2016 hingga April 2017. Populasi penelitian ini adalah semua pekerja PKS X. Sampel penelitian adalah sebagian dari anggota populasi yang diperiksa oleh peneliti dan memenuhi kriteria inklusi. Kriteria inklusi pada penelitian: 1) laki-laki berusia 18-40 tahun; 2) masa kerja lebih atau 
sama dengan 5 tahun; 3) perokok aktif ataupun bukan perokok (pembanding), 4) terpapar bising lebih besar atau sama dengan $85 \mathrm{~dB}$ selama 8 jam; 5) pada pemeriksaan Telinga Hidung Tenggorok - Bedah Kepala Leher rutin dan anamnesis tidak dijumpai kelainan dan riwayat yang memengaruhi fungsi pendengaran; 6) bersedia diikutsertakan dalam penelitian dan menandatangani informed consent.

Tipe perokok dalam penelitian ini dibagi berdasarkan banyaknya rokok yang dikonsumsi dalam sehari: 1) perokok ringan, apabila jumlah rokok yang dikonsumsi dalam sehari kurang dari 10 batang, 2) perokok sedang, apabila rokok yang dikonsumsi 11-20 batang dalam sehari, 3) perokok berat, apabila jumlah rokok yang dikonsumsi sebayak 21-30 batang, dan 4) perokok sangat berat, apabila rokok yang dikonsumsi lebih dari 30 batang dalam sehari

Jumlah sampel didapati sebanyak 122 pekerja, yaitu terdiri dari perokok berjumlah 61 pekerja dan bukan perokok sebanyak 61 pekerja. Dilakukan pemeriksaan pendengaran dengan menggunakan audiometer nada murni dengan menggunakan frekuensi $125-8000 \mathrm{~Hz}$ untuk hantaran udara dan 250-4000 Hz untuk hantaran tulang. Derajat ketulian ditentukan dengan mengukur nilai rerata ambang pendengaran pada frekuensi percakapan (500 $\mathrm{Hz}, 1000 \mathrm{~Hz}, 2000 \mathrm{~Hz}$ dan $4000 \mathrm{~Hz}$ ).

Data dianalisis menggunakan SPSS 21 secara analitik dengan uji Chi-square untuk melihat hubungan antara variabel dependen

Tabel 1. Proporsi gangguan pendengaran pekerja

\begin{tabular}{lcc}
\hline $\begin{array}{l}\text { Gangguan } \\
\text { pendengaran }\end{array}$ & Jumlah (\%) & $\begin{array}{c}\text { Persentase } \\
(\%)\end{array}$ \\
\hline Positif & 109 & 89,3 \\
Negatif & 13 & 10,7 \\
\hline Total & 122 & 100 \\
\hline
\end{tabular}

dan independen. Penelitian ini telah mendapat persetujuan dari Komisi Etik Penelitian Fakultas Kedokteran Universitas Sumatera Utara.

\section{HASIL}

Didapatkan rerata intensitas bising alatalat yang digunakan pada 8 station PKS X adalah 88,9 ( $\mathrm{SD} \pm 4,89)$. Didapatkan sebanyak 109 orang $(89,3 \%)$ pekerja mengalami gangguan pendengaran dan sebanyak 13 orang $(10,7 \%)$ pekerja memiliki pendengaran yang normal (tabel 1).

Diperoleh proporsi tingkat gangguan pendengaran yang diperiksa dengan menggunakan audiometri nada murni sebanyak 13 orang pekerja $(10,7 \%)$ memiliki pendengaran yang normal, 84 orang pekerja $(68,8 \%)$ mengalami gangguan pendengaran ringan, dan 25 orang pekerja $(20,5 \%)$ mengalami gangguan pendengaran sedang (tabel 2).

Didapatkan adanya hubungan yang signifikan antara tipe perokok dengan derajat gangguan pendengaran $(p=0,000)$ yang dapat dilihat pada tabel 3. Serta dari tabel 3 dapat dilihat adanya hubungan yang signifikan antara perilaku merokok dengan gangguan pendengaran $(\mathrm{p}=0,001)$. Didapatkan prevalence ratio sebesar 1,224 (CI 95\%, 1,077-1,392) yang berarti perokok 1,224 kali lebih besar kemungkinannya untuk mengalami gangguan pendengaran apabila dibandingkan dengan bukan perokok yang sama-sama terpapar bising (tabel 4).

Tabel 2. Proporsi tingkat gangguan pendengaran

\begin{tabular}{lcc}
\hline $\begin{array}{l}\text { Gangguan } \\
\text { pendengaran }\end{array}$ & Jumlah (\%) & $\begin{array}{c}\text { Persentase } \\
(\%)\end{array}$ \\
\hline Normal & 13 & 10,7 \\
Tuli ringan & 84 & 68,8 \\
Tuli sedang & 25 & 20,5 \\
\hline Total & 122 & 100 \\
\hline
\end{tabular}


Tabel 3. Hubungan tipe perokok dengan derajat GPAB pada tenaga kerja

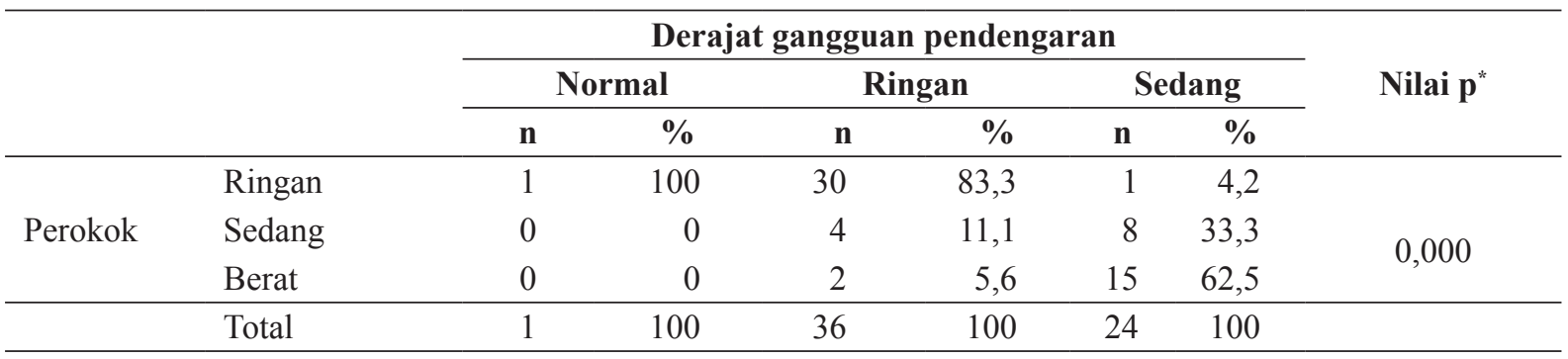

*Uji Kolmogorov Smirnov

Tabel 4. Hubungan merokok dengan GPAB pada tenaga kerja

\begin{tabular}{|c|c|c|c|c|c|c|}
\hline & & \multicolumn{4}{|c|}{ Gangguan pendengaran } & \multirow{3}{*}{ Nilai $p^{*}$} \\
\hline & & \multicolumn{2}{|c|}{ Negatif } & \multicolumn{2}{|c|}{ Positif } & \\
\hline & & n & $\%$ & n & $\%$ & \\
\hline \multirow{3}{*}{$\begin{array}{l}\text { P e ri la k u } \\
\text { merokok }\end{array}$} & Perokok & 1 & 7,7 & 60 & 55 & \multirow{2}{*}{0,001} \\
\hline & Bukan perokok & 12 & 92,3 & 49 & 45 & \\
\hline & Total & 13 & 100 & 109 & 100 & \\
\hline
\end{tabular}

"Uji Fischer's Exact

Prevalence Ratio $=1,224$

\section{DISKUSI}

Bising merupakan hal yang paling berbahaya di tempat kerja. Sekitar 30 juta pekerja Amerika terpapar dengan bising di tempat kerja mereka dan diperkirakan sekitar 600 juta orang pekerja di seluruh dunia terpapar dengan bising lingkungan kerja. Nilai ambang batas (NAB) yang diperbolehkan oleh National Institute for Occupational Safety and Health (NIOSH) dan kementerian tenaga kerja Indonesia adalah sebesar $85 \mathrm{~dB}$ selama 8 jam. Apabila seorang pekerja terpapar bising di atas NAB secara terus-menerus dalam waktu lama, maka dapat mengalami GPAB. Meskipun GPAB ini bersifat permanen, irreversible dan sering terjadi, akan tetapi GPAB dapat dicegah. Dari penelitian ini didapati bahwa rerata intensitas bising yang berasal dari alat-alat yang digunakan di PKS X adalah sebesar 88,9 dB ( $\mathrm{SD} \pm 4,89)$. Pajanan bising ini melebihi batas yang diperbolehkan, sehingga untuk pencegahan terjadinya GPAB, pihak perusahaan menyarankan seluruh karyawan yang terpapar bising untuk menggunakan alat pelindung telinga (APT). Akan tetapi dari hasil wawancara ditemukan bahwa seluruh karyawan tidak menggunakan APT dengan alasan mereka merasa sulit untuk berkomunikasi apabila menggunakan APT. ${ }^{11,12}$

Pada penelitian ini didapati tuli ringan pada 84 orang pekerja $(68,8 \%)$, merupakan gangguan pendengaran yang paling banyak, kemudian diikuti tuli sedang sebanyak 25 orang pekerja (20,5\%). Dari penelitian ini didapati bahwa proporsi pekerja yang mengalami gangguan pendengaran adalah sebanyak 109 orang pekerja $(89,3 \%)$, sedangkan yang tidak mengalami gangguan pendengaran atau pendengaran normal sebanyak 13 orang pekerja $(10,7 \%)$. Hal ini sejalan dengan penelitian Silitonga ${ }^{13}$ pada tahun 2014, didapatkan pekerja yang terpapar bising lingkungan kerja melebihi $85 \mathrm{~dB}$ lebih banyak mengalami gangguan pendengaran $(53,6 \%)$ dibandingkan dengan yang tidak. Hal yang berbeda ditemukan oleh Dib et $\mathrm{al}^{3}$ pada tahun 2008, ditemukan 50\% pekerja mengalami gangguan pendengaran, yang berarti pekerja yang mengalami gangguan pendengaran sama banyaknya dengan pekerja yang mempunyai pendengaran normal. Juwarna ${ }^{14}$ tahun 2013 mendapati 44,44\% pekerja yang terpapar bising diatas $85 \mathrm{~dB}$ mengalami 
gangguan pendengaran. Hal ini menunjukkan lebih banyak pekerja yang mempunyai pendengaran normal dibandingkan dengan yang mengalami gangguan pendengaran. Besarnya perbedaan angka kejadian gangguan pendengaran kemungkinan dipengaruhi oleh tidak digunakannya APT selama bekerja di lingkungan bising, yang pada akhirnya akan berdampak terhadap pendengaran pekerja. ${ }^{11,12}$

Ada faktor-faktor lain yang berpengaruh terhadap terjadinya GPAB antara lain frekuensi bising, periode pajanan setiap hari, kepekaan individu, usia, penyakit sistemik, kebiasaan merokok, dan lain-lain. Kebiasaan merokok dan paparan bising dipercaya sebagai faktor penting yang dapat meningkatkan kemungkinan untuk mengalami gangguan pendengaran. Penelitian ini bertujuan untuk melihat hubungan kebiasaan merokok dengan kejadian GPAB pada pekerja yang terpapar bising lingkungan kerja, mengingat bahwa merokok merupakan kebiasaan yang paling umum dijumpai pada semua lapisan sosial, termasuk pekerja pabrik. ${ }^{11,12}$

Pada penelitian ini, untuk melihat hubungan perilaku merokok dengan gangguan pendengaran dilakukan analisis menggunakan tes Fischer Exact dan didapatkan nilai $\mathrm{p}=0,002$. Ada hubungan yang signifikan antara perilaku merokok dengan gangguan pendengaran. Didapatkan prevalence ratio (PR) sebesar 1,224 (CI 95\% 1,077-1,392) yang artinya perokok mempunyai kemungkinan 1,224 kali lebih besar untuk mengalami gangguan pendengaran apabila dibandingkan dengan bukan perokok. Temuan ini sejalan dengan penelitian Tao et $\mathrm{al}^{8}$ tahun 2013 yang mendapatkan pekerja yang merokok 1,94 kali lebih besar untuk mengalami gangguan pendengaran dibandingkan dengan yang tidak merokok. Hasil penelitian ini sejalan juga dengan penelitian yang dilakukan Mizoue, Miyamoto, dan Shimizu ${ }^{9}$ yang mendapatkan bahwa pekerja yang merokok 1,8 kali lebih besar untuk mengalami gangguan pendengaran dibandingkan dengan pekerja yang tidak merokok dan sama-sama terpapar bising lingkungan kerja. Dari penelitianpenelitian di atas dapat dilihat bahwa pekerja yang merokok mempunyai kecenderungan untuk mengalami gangguan pendengaran lebih besar apabila dibandingkan dengan pekerja yang tidak merokok, dan sama-sama terpapar bising. Paparan bising selain mengakibatkan kerusakan pada reseptor pendengaran organ korti di telinga dalam juga mengakibatkan menurunnya aliran darah koklea yang mengakibatkan keadaan hipoksia koklea. Merokok dilaporkan dapat berperan sebagai ototoksik langsung (efek nikotin), dan sebagai pemicu terjadinya iskemia koklea melalui mekanisme produksi karboksihemoglobin, vasospasme, meningkatkan viskositas darah. Mekanisme inilah yang kemudian dapat mengakibatkan gangguan pendengaran. Adanya perbedaan nilai yang didapat pada penelitian-penelitian di atas kemungkinan disebabkan oleh adanya perbedaan kriteria gangguan pendengaran yang dianut di setiap penelitian. ${ }^{8,9}$

Pada penelitian ini, berdasarkan hasil uji Kolmogorov Smirnov didapatkan $\mathrm{p}=0,000$ yang berarti dijumpai adanya hubungan yang signifikan antara tipe perokok dengan derajat gangguan pendengaran. Temuan ini sesuai dengan penelitian Mohammadi et $\mathrm{al}^{10}$ pada tahun 2010 yang menyatakan adanya hubungan yang signifikan antara jumlah rokok yang dikonsumsi dengan gangguan pendengaran. Penelitian Mizoue, Miyamoto, dan Shimizu di tahun 2003 juga mendapati hubungan yang signifikan antara banyaknya rokok yang dikonsumsi dengan kejadian gangguan pendengaran, risiko gangguan pendengaran meningkat sejalan dengan bertambahnya jumlah rokok yang dikonsumsi. Hal ini kemungkinan disebabkan oleh meningkatnya jumlah rokok yang dikonsumsi, sehingga semakin tinggi dan sering tubuh perokok terpapar dengan zat-zat yang berperan pada mekanisme gangguan pendengaran, seperti nikotin dan karbon monoksida. ${ }^{8,9}$ 
Pada penelitian ini proporsi GPAB pada tenaga kerja PKS X adalah sebesar 89,3\% (109 orang). Tingkat gangguan pendengaran yang paling banyak adalah tuli ringan sebanyak 84 orang pekerja $(68,8 \%)$. Terdapat hubungan yang signifikan antara kebiasaan merokok dengan derajat beratnya gangguan pedengaran dan ditemukan hubungan yang signifikan antara kebiasaan merokok dengan kejadian GPAB pada pekerja yang terpapar bising. Didapati bahwa pekerja yang merokok mengalami gangguan pendengaran 1,224 kali lebih besar apabila dibandingkan dengan pekerja yang tidak merokok.

Sebaiknya dapat dilakukan pemeriksaan audiometri berkala secara rutin pada pekerja di lingkungan bising. Apabila memungkinkan dilakukan rotasi pekerja di tempat bising ke tempat yang tenang secara berkala untuk mengurangi pekerja terlalu lama terpapar dengan bising serta untuk mengurangi angka kejadian GPAB. Para pekerja diwajibkan untuk menggunakan APT guna menurunkan angka kejadian GPAB, serta pihak pabrik perlu untuk mengawasi ketaatan pekerja untuk menggunakan APT. Selain itu dianjurkan dilakukan penyuluhan secara teratur mengenai dampak merokok terhadap gangguan pendengaran akibat bising, untuk meningkatkan kesadaran pekerja terhadap dampak merokok terhadap gangguan pendengaran akibat bising.

\section{DAFTAR PUSTAKA}

1. Bashiruddin J. Pencegahan gangguan pendengaran, tantangan dan harapan dalam implementasi program sound hearing. Disampaikan pada Pidato Pengukuhan Guru Besar THT KL FK UI, Jakarta, 2010.

2. Nelson D. The global burden of occupational noise-induced hearing loss. American Journal of Industrial Medicine. 2005; 48(6):446-58.
3. Dib R, Silva E, Morais J, Trevisani V. Prevalence of high frequency hearing loss consistent with noise exposure among people working with sound systems and general population in Brazil : a cross sectional study. BioMedCentral Public Health. 2008; $8(151): 1-8$

4. Balitbang Kemenkes RI. 2013. Riset Kesehatan Dasar. Badan Penelitian dan Pengembangan Kesehatan Kementerian Kesehatan RI Tahun 2013. Jakarta, 2013.

5. Rianto B, Sugicharto M, Soewito. Pengaruh paparan asap rokok pada koklea, studi pada tikus putih (Rattus novergicus). Disampaikan pada Kongres Nasional XVI PERHATI-KL, Medan, 2013.

6. Carmelo A, Concetto G, Agata Z, Antonietta TM, Graziella D, Renato B, et al. Effect of cigarette smoking on the evolution of hearing loss caused by industrial noise. Health Journal. 2010; 2(10):1163-9.

7. Pamukcu B, Oflaz H, Onur I, Cimen A, Nisanci Y. Effect of cigarette smoking on platelet aggregation. Clinical and Applied Thrombosis/Hemostasis. 2011; 17(6):175-9.

8. Tao L, Davis R, Heyer N, Yang Q, Qiu W, Zhu L, et al. Effect of cigarette smoking on noise-induced hearing loss in workers exposed to occupational noise in China. Noise \& Health. 2013; 15(62):67-72.

9. Mizoue T, Miyamoto T, Shimizu T. Combined effect of smoking and occupational exposure to noise on hearing loss in steel factory workers. Occupational and Environmental Medicine. 2003; 60(1):56-9.

10. Mohammadi S, Mazhari MM, Mehrparvar AH, Attarchi MS. Effect of simultaneous exposure to occupational noise and cigarette smoke on binaural hearing impairment. Noise and Health. 2010; 12(48):187-90.

11. Tana L, Halim S, Ghani L, Delima. Gangguan pendengaran akibat bising pada pekerja perusahaan baja di pulau Jawa. Jurnal Kedokteran Trisakti. 2002; 21(3):84-9. 
12. Pouryaghoub G, Mehrdad R, Mohammadi S. Interaction of smoking and occupational noise exposure on hearing loss: a crosssectional study. BMC Public Health. 2007; $7: 137$.

13. Silitonga N. Hubungan kebisingan dengan pendengaran pekerja (Studi Kasus A,B,C Di Kota Medan). Tesis. Medan : Magister Kedokteran Klinik Universitas Sumatera Utara; 2014.

14. Juwarna W. Gangguan pendengaran akibat bising pada karyawan Pabrik Kelapa Sawit (PKS) Begerpang PT.PP. Lonsum. Tesis. Medan: Magister Kedokteran Klinik Universitas Sumatera Utara; 2013. 